\title{
Development Model of Creative Industries: An Application of MACTOR
}

\section{Liana Mangifera and Muzakar Isa}

Faculty of Economics and Business, Universitas Muhammadiyah Surakarta, Jl. A. Yani Pabelan Kartasura 57102 Surakarta

\section{Abstract}

This study aims to identify the role of stakeholders in the development of creative industries in Sukoharjo district and formulate models of creative industry development through the patterns of stakeholder relationships involved. This research uses descriptive method. The analytical method uses MACTOR analysis to explain the relationship and role of stakeholders in developing creative industry. The results show that stakeholders representing the main players of creative economic development in Sukoharjo are the Department of Planning, Regional Research and Development,

Corresponding Author: Liana Mangifera liana.mangifera@ums.ac.id

Received: 18 January 2019 Accepted: 24 March 2019 Published: 31 March 2019

Publishing services provided by Knowledge E

(c) Liana Mangifera and Muzakar Isa. This article is distributed under the terms of the Commons Attribution License, which permits unrestricted use and redistribution provided that the original author and source are credited.

Selection and Peer-review under the responsibility of the First ELEHIC Conference Committee. the Department of SME, the Department of Trade, the Department of Industry and Manpower and, the University, FEDEP, the Craft Association, and Entrepreneur. Stakeholders with the highest influence are SMIEs, so that they can be central figures in the development of creative industries. While the objectives consisting of Advantages, profit, network, main duty, and Local Income (PAD) received a positive response from all actors, meaning that all actors agreed with the objectives, and convergence was divided into two groups according to the interests of each stakeholder with the interests of each stakeholder. The problem of developing creative industries Sukoharjo is a complex problem that cannot be seen partially because it involves not only economic but also social, cultural and political issues. Not all stakeholders are actively involved in the development of creative economy and every stakeholder has different interests optimizing the development of creative industries is required model of coordination framework among stakeholders in the development of creative industries in Sukoharjo District.

Keywords: creative industry, handicraft, interest, influence, interdependence, stakeholders.

\section{Introduction}

The creative industry is one sector that is expected to become a new economic power in the future along with the condition of natural resources dwindling each year. The development of creative industries is the right choice to keep the economy under the 
conditions of the global crisis. Creative industries can provide a very significant contribution to the economy of the region. Its existence is a part which cannot be separated. According to UNCTAD (2008), many of the creative industries contribute significantly on the economy, namely, an increase in export values, absorption of labor, as well as a contributor to gross domestic product (GDP). The results of the study supported the opinion of the decision explains the creative industries to contribute significantly to the growth of the national economy. In the year 2015, the creative economy sector contributed 852 trillion rupiah against the national GDP (7.38\%), absorbing 15.0 million labor (13.90\%), and export value US $\$ 19.4$ billion (12.88\%). National data shows an increase in the contribution of the creative economy significantly to the national economy from the years 2010-2015, that amounted to $10.14 \%$ per year (BPS, 2017).

According to the Agency for the Creative Economy (2016) Creative economic policy direction is to develop superior research and human resource competency on the creative economy sector, increase access to capital for the creative economy, facilitating the availability of infrastructure sectors, increasing the creative sector of the creative economy, increasing economic benefits to the holders of intellectual property rights in the creative sector of the economy, build and strengthen the institutional and regulatory in the creative sector of the economy, established the implementation of the reform of the bureaucracy and the Government's good governance. From a wide diversity of creative economic potential in Indonesia, the Government of Indonesia focus on 16 subsector. The Presidential Regulation Number 72/2015 about changes to The Presidential Regulation number 6/2015 about Creative Economy Agency reclassify had sub-sector creative industry sub-sectors of 15 to 16 sub-sectors, namely the culinary; architecture; product design; interior design; graphic design; film, animation and video; music; fashion; performing arts; games and applications; craft; radio and television; fine art; advertising; photography; as well as publishing.

Creative industries Sukoharjo Regency potentially developed by businessmen. Economic growth in Sukoharjo Regency widely supported by the industry sector, one of the creative industry. In 2015 the industry sector was the sector most contributed to GDP Sukoharjo Regency i.e. 10.368 trillion, or $38.87 \%$. However, if seen from the growth rate for the year 2011-2015 show the numbers decreased. In the year 2015 growth amounted to $2.98 \%$ decrease compared to the year 2014 of $6.54 \%$. Potential handicraft products in Sukoharjo Regency which are rattan, loom, guitar, goyor gloves, glass carvings, calligraphy, gamelan, bark, herbs and batik [1] The existence of the creative industry in Sukoharjo Regency is prevalent in some districts. Gamelan is located in Wirun Mojolaban, guitar is located in Grogol, Shuttelcok is located in Gadingan Mojolaban, Rattan craft 
is located in Trangsang Gatak; grafir in Manang Baki, creative tourist village is located in Kenep Sukoharjo. This creative industry contributes to some aspect of life, not only in terms of sheer economic, but also give a positive impact to other aspects such as improvement of the image and identity of the nation, fostering innovation and creativity of the nation, the industry is using renewable resources, as well as positive social impact.

Competitive creative industries that increasingly stringent demands the perpetrators attempt to more creative in determining its business strategy so that was able to compete [1]. The development of creative industries in Sukoharjo Regency became very important given the magnitude of the potential of the creative industry and its contribution. Creative industries need to be developed, because the creative industries have a significant economic contribution to the region's economy and create a positive business climate, can strengthen the image of regional identity, supporting \& utilization of renewable resources, is central to the creation of innovation and creation of creativity, and have a positive social impact. The stages of creative industry development driven by the thought that the stakeholders (academics, business and Government) are together delivering the Foundation and pillars form the pillars of the current leads to conditions expected through its role of each form.

This study aims to identify the stakeholders involved in the development of creative industry, describe the various interests of stakeholders in the creative industry and formulate model for developing creative industry in Sukoharjo regency.

\section{Material and Method}

This research uses a mixed method, which combines quantitative and qualitative analyses. The key persons were selected through snowball sampling method by considering its suitability for identifying respondents who directly related to the study site and the efforts of creative industries development. Based on the method, 11 respondents were selected as key informants of creative industries development.

In-depth interviews were carried out to obtain specific information to answer research problems and research objectives by listing questions as a guide for interviewing respondents and key informants. Interviews were conducted on selected key informants who deliberately selected based on their involvement and comprehension in issues related to creative industries development.

In this research uses stakeholder analysis. Stakeholder analysis was employed to analyze the involved stakeholders in the effort of creative industries development. Hermans and Thissen (2008) suggested stakeholder analysis as a study undertaken to identify 
and map stakeholders based on their role and impact in creative industries development. The ultimate goal was to identify complex multi-stakeholder and to determine the most significant stakeholders in association with creative industries development [2].

The analytical tool used is the Matrix of Alliance and Conflict: Tactics, Objectives, and Recommendations (MACTOR). MACTOR (Matrix of Alliance and Conflict: Tactics, Objectives, and Recommendations) is an analytical tool used to analyze influences and interests (objectives) of stakeholders. This method is very broad because it can be used for up to 20 related purposes and yet simple and accessible. To obtain accurate results of analysis, an in-depth interview by using questionnaires is required to obtain more comprehensive answer from stakeholders $[3,4]$. MACTOR includes several stages of matrix preparation, namely: (1) determination of key variables and relevant actors; (2) preparation of table of actors; (3) preparation of strategic issues and objectives; (4) determination of actors and strategic objectives in the matrix; (5) calculation of convergence and divergence matrices as performed in three stages; (6) calculation of the direct and indirect relationship of power matrix; (7) calculation of the position matrix value; (8) analysis of strategic recommendations of each actor [3].

\section{Results and Discussion}

The processing industry has a large contribution to the economy of Sukoharjo regency. The contribution of the processing industry to the Sukoharjo economy is about 39\%. The growing processing industry in Sukohajo Regency is a creative industry type of craft group. In 2016, the number of manufacturing industries is 17,054 business units, with this number increasing every year (BPS Sukoharjo, 2018).

TABLE 1: Number of Industries at Sukoharjo 2017.

\begin{tabular}{|c|c|c|c|c|}
\hline \multirow[t]{2}{*}{ Industry } & \multicolumn{3}{|c|}{ Kelompok industri } & \multirow[t]{2}{*}{ Total } \\
\hline & $\begin{array}{l}\text { Agro Industry and } \\
\text { Forest Products }\end{array}$ & $\begin{array}{l}\text { Industry of Textile } \\
\text { and Multifarious }\end{array}$ & $\begin{array}{l}\text { Industry of Chemical, } \\
\text { Metals, Machinery, and } \\
\text { Electrical }\end{array}$ & \\
\hline Small & 62 & 30 & 33 & 125 \\
\hline Medium & 162 & 70 & 88 & 320 \\
\hline Big & 6.881 & 4.323 & 5.405 & 16.609 \\
\hline Total & 6.105 & 4.423 & 5.526 & 17.054 \\
\hline
\end{tabular}


Creative industry in Sukoharjo district has great potential, and also has problems that are not small. The main problem of creative industry in Sukoharjo Regency is coordination and cooperation between stakeholders that have not been optimal yet. This is because there is no study that discusses the analysis of stakeholders. Based on in-depth interview, there are 11 stakeholders representing the main actors of creative industries development in Sukoharjo. They are (1) Department of Planning; Research and Regional Development; (2) Department of SMEs; (3) Department of Commerce; (4) Department of Industry and Labor and, (5) University; (6) FEDEP; (7) Association; (8) Furniture SMEs; (9) Rattan SMEs, (10) Batik SMEs, and (11) Tenun SMEs. The Objectives of creative industries development are (a) profit, (b) main duty, (c) network, (d) the original regional revenue (PAD).

The Mactor Analysis results explain that the influence and interdependence between actors shows how strong the competitiveness of stakeholders in determining the policy to be formulated. The higher the competitiveness, the stronger the influence of stakeholders in accommodating the interests of each stakeholder. The result of Mactor also indicate the level of approval of the actor against the objectives to be formulated. Furthermore, the result of Mactor will show the convergence and divergence between actors. The first result shows the map of influence and interdependence among actors is a representation of the position of each actor with influence and dependence on each other.

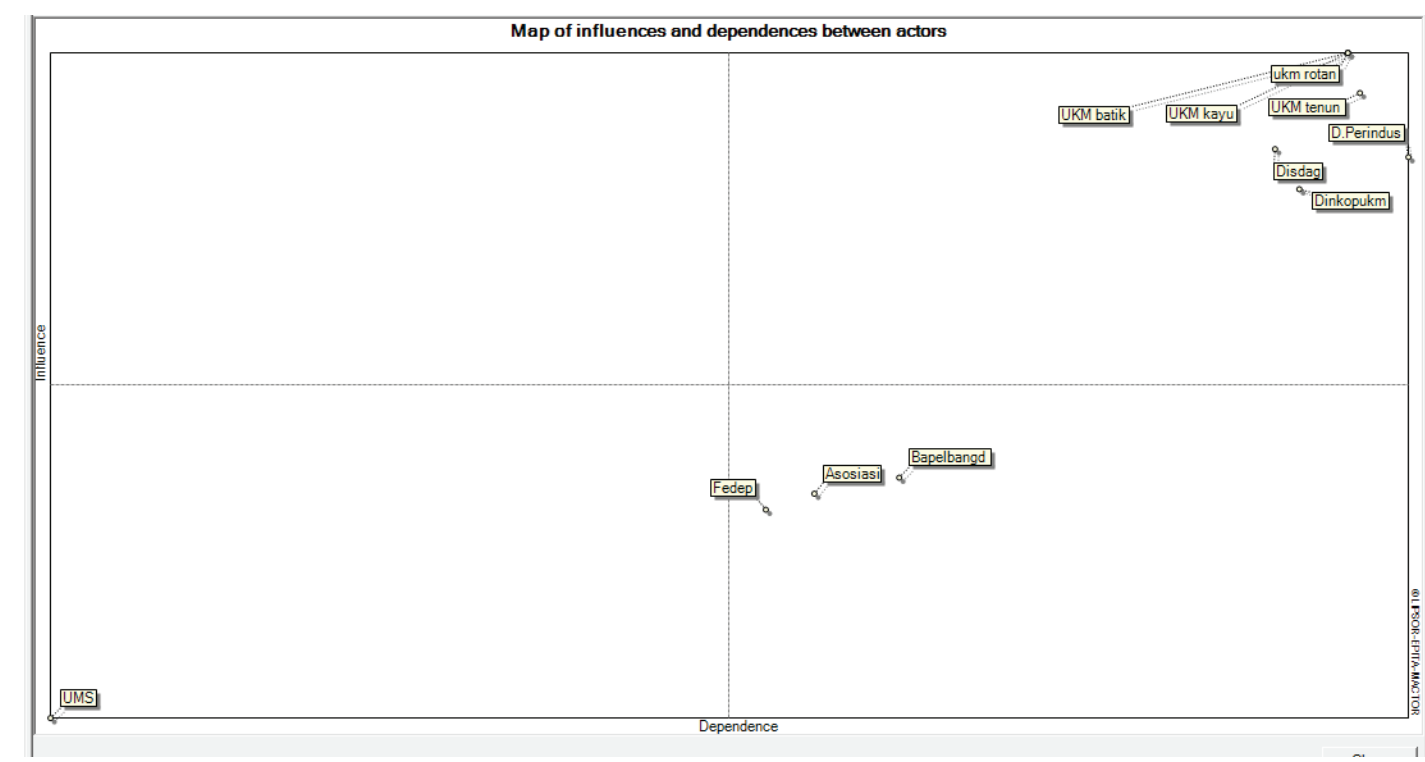

Figure 1: Map of Stakeholders' Influence and Relationship in Creative Economic Development Source: Stakeholder Analysis based on MACTOR (2018).

Figures 2 and 3 show that SMEs have the highest influence so that their competitiveness is high [5]. These results indicate that SMEs have a central role in develop of creative 
TABLE 2: Roles of Stakeholders for Developing Creative Industry.

\begin{tabular}{|c|c|c|}
\hline NO & ACTORS & ROLES OF STAKEHOLDERS \\
\hline \multirow[t]{2}{*}{1} & $\begin{array}{l}\text { Department of } \\
\text { Planning; Research and } \\
\text { Regional Development }\end{array}$ & 1. The study of creative industry development \\
\hline & & $\begin{array}{l}\text { 2. Interagency coordination in the development of creative } \\
\text { industries }\end{array}$ \\
\hline \multirow[t]{2}{*}{2} & Department of SMEs & 1. SMEs business management training \\
\hline & & 2. Intellectual Property Rights \\
\hline \multirow[t]{2}{*}{3} & $\begin{array}{l}\text { Department of } \\
\text { Commerce }\end{array}$ & 1. Promotion of creative products through exhibitions, galleries \\
\hline & & 2. Build networking and product bundling \\
\hline \multirow[t]{2}{*}{4} & $\begin{array}{l}\text { Department of Industry } \\
\text { and Labor }\end{array}$ & 1. Creative product innovation training \\
\hline & & 2. Labor Training \\
\hline \multirow[t]{2}{*}{5} & University & $\begin{array}{l}\text { 1. Training and development of human resources, finance, } \\
\text { marketing and production }\end{array}$ \\
\hline & & 2. Business motivation training and entrepreneurship \\
\hline \multirow[t]{2}{*}{6} & FEDEP & 1. Assistance of creative cluster members \\
\hline & & 2. Coordination of creative cluster members \\
\hline \multirow[t]{2}{*}{7} & Association & 1. Network development among creative business actors \\
\hline & & 2. Development of associate members \\
\hline \multirow[t]{2}{*}{8} & Furniture SMEs & 1. Producing furniture and innovating new products \\
\hline & & 2. Produce various handicrafts with wood raw materials \\
\hline \multirow[t]{2}{*}{9} & Rattan SMEs & 1. Producing rattan furniture and innovating new products \\
\hline & & 2. Produce various products from rattan. \\
\hline \multirow[t]{2}{*}{10} & Batik SMEs & 1. Producing batik cloth and innovating new products \\
\hline & & 2. Produce batik clothes and various handicrafts from batik cloth \\
\hline \multirow[t]{2}{*}{11} & Lurik SMEs & 1. Produce various lurik fabrics and innovate new products \\
\hline & & 2. Producing lurik clothes and crafts from lurik fabrics. \\
\hline
\end{tabular}

industries in Sukoharjo. The actor with the lowest influence and high dependence is university.

The next goal is to analyze stakeholder perceptions of the objectives that become indicators. The competitiveness and objectives scale shows that profit, network, main duty, and the original regional revenue (PAD) receive positive response from all actors, meaning that all actors agree with these objectives. 


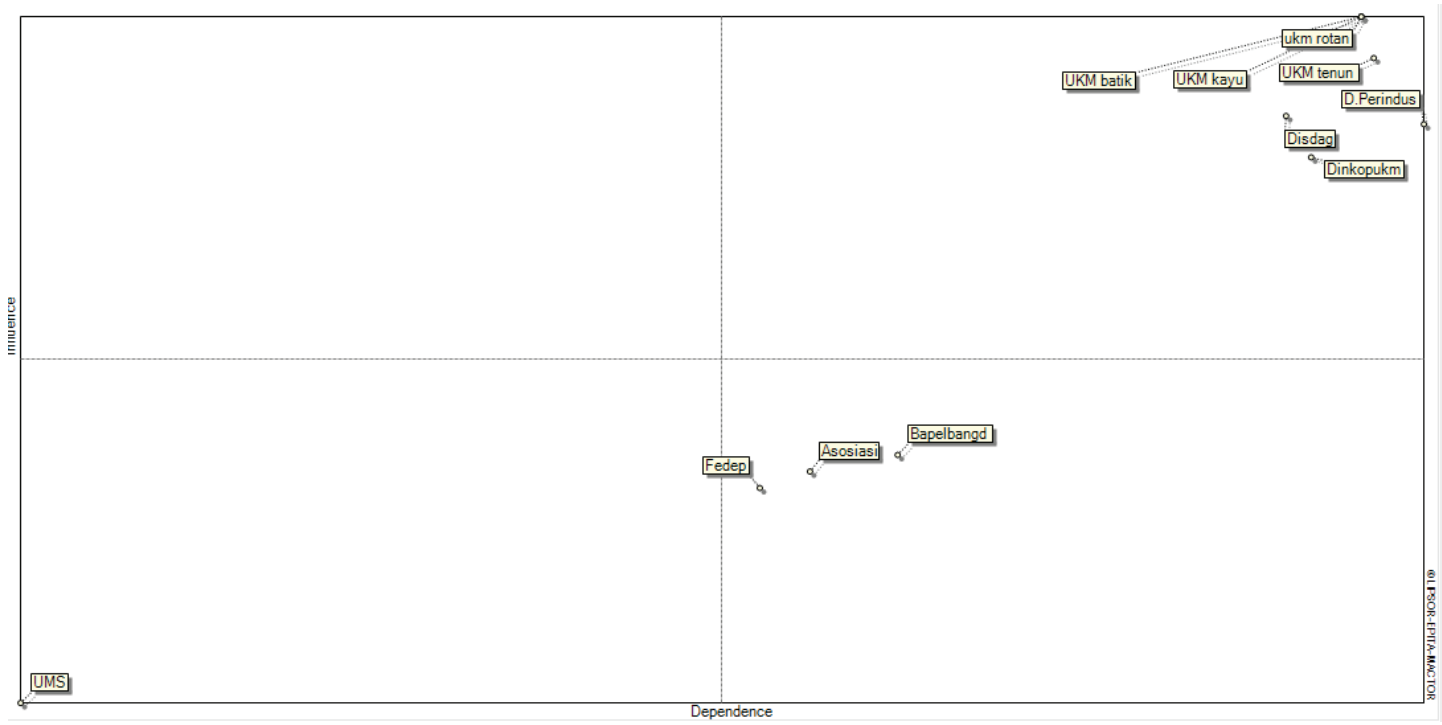

Figure 2: Influence and Dependency Map Between Actors Source: Stakeholder Analysis based on MACTOR (2018).

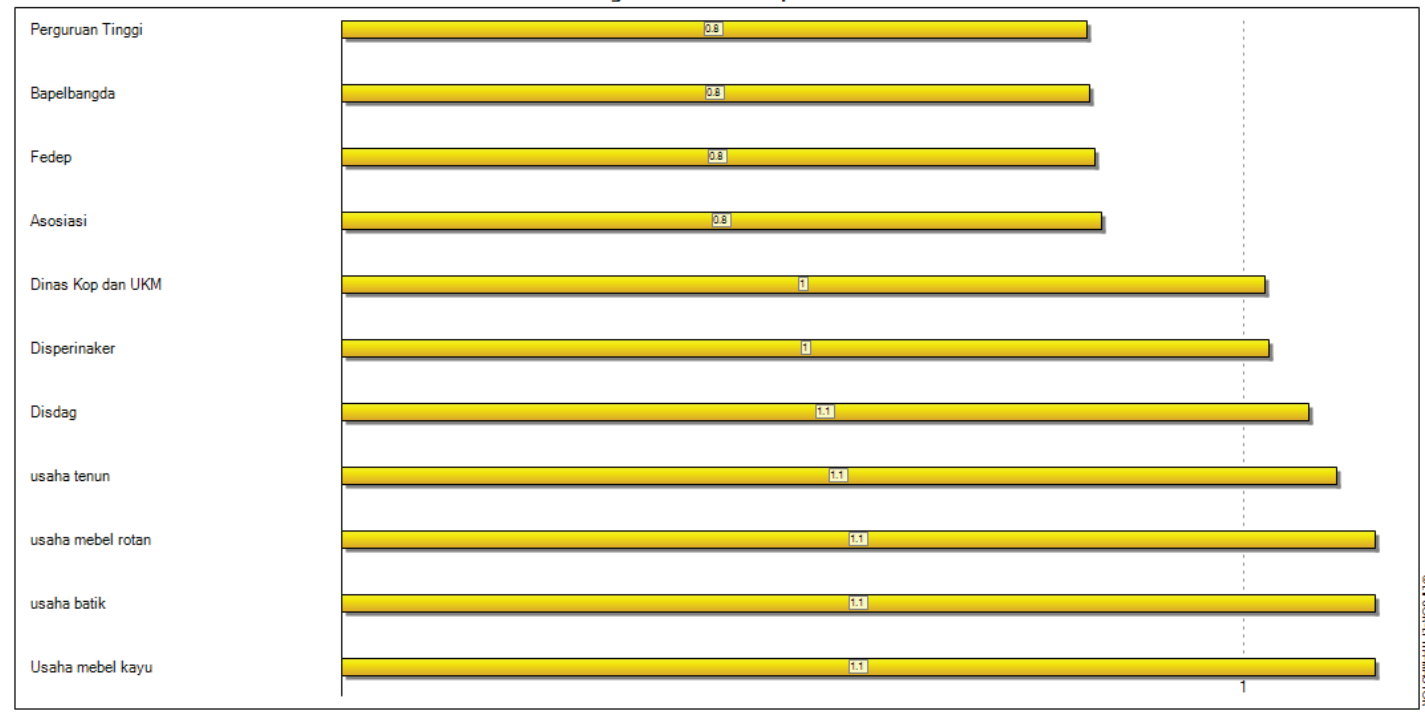

Figure 3: Histogram of Matrix Direct and Indirect Competitiveness Source: Stakeholder Analysis based on MACTOR (2018).

Figure 4 and 5 shows the objectives of stakeholders are situated in the upper left quadrant, implying they have high influence and low dependence of other variables in creative industries development. These objectives have major influence in developing creative industries. These objectives are the key objectives that are critical in the success of creative industries development efforts. They are original regional revenue (PAD) and network. Meanwhile, humanity raises awareness and empathy to others. These two objectives have an impact on developing creative industries. The right-bottom quadrant is dependent factors (weak driver - strongly dependent variables). The quadrant includes objectives that have a weak driving force and strong dependence. The element in this 


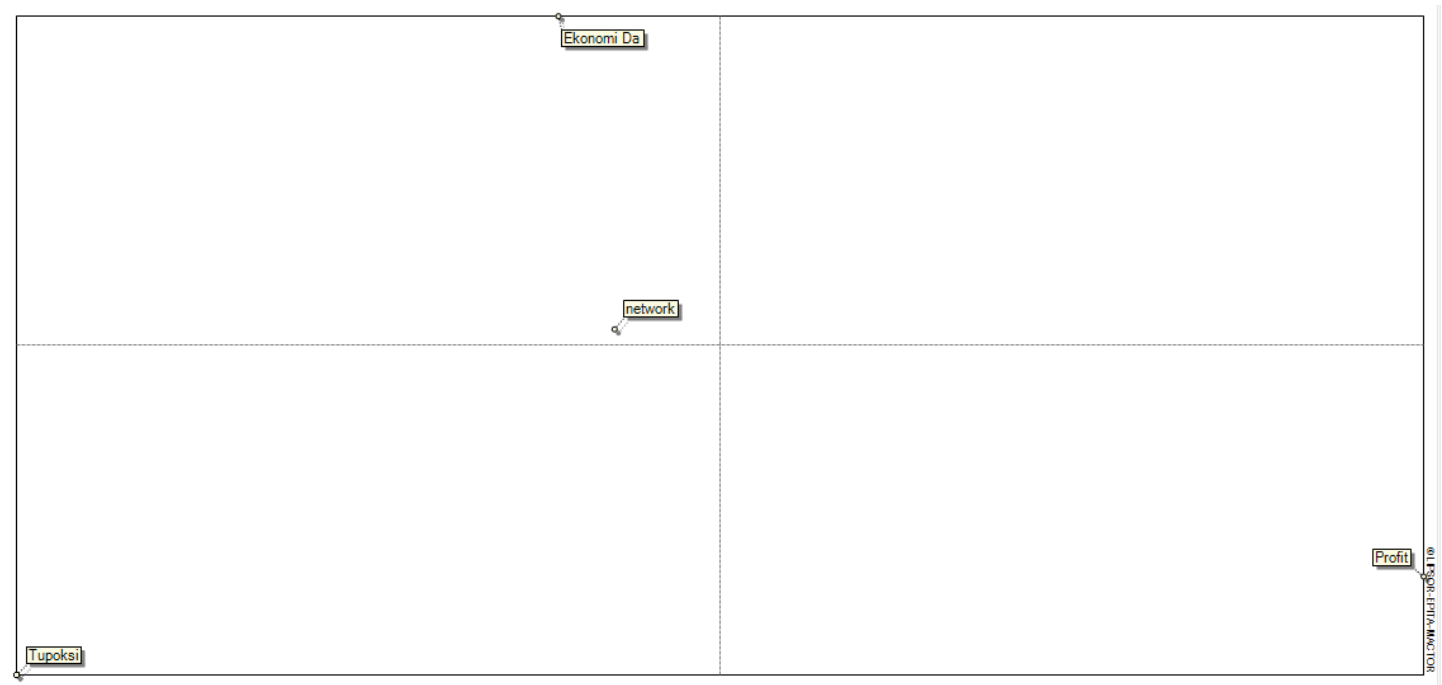

Figure 4: Map of stakeholders Objectives of Creative Economic Development Source: Stakeholder Analysis based on MACTOR (2018).

\section{Graph of net distances between objectives}

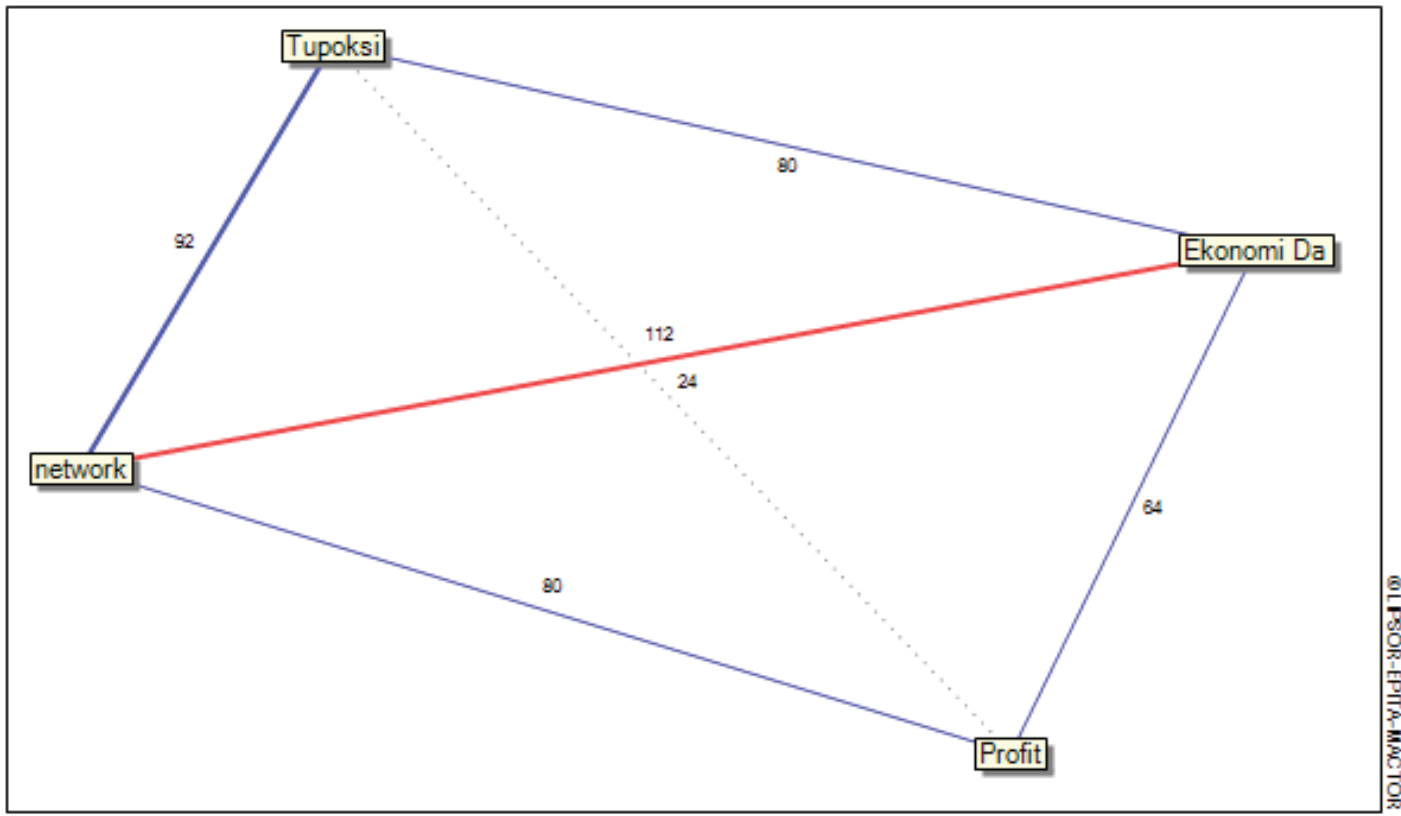

Shortest net distances

Short net distances

- Moderate net distances

- Long net distances

- Longest net distances

Figure 5: Graph of stakeholders objectives of Creative Economic Development Source: Stakeholder Analysis based on MACTOR (2018).

awareness is a non-independent element. Profit is classified in this quadrant. This is the objective of several stakeholders in conducting activities of creative industries development. The lift-bottom quadrant is dependent factors (weak driver - weak dependent variables). The quadrant includes objectives that have a weak driving force and weak 
dependence. The objective is less related to develop of creative industries and may have few relationships that will be eliminated from the objectives of stakeholders in creative industries development.

Convergence among actors on creative industries development shows strong values in Department of Planning, Research and Regional Development (Bappelbangda), Department of SMEs, Department of Commerce, Department of Industry and Labor and, Community, and Craft Association which shows the important position of these actors as they have a high degree of common interest. Stakeholders with the lowest convergence are businessman and academic. The low convergence is related to their high competitiveness, which makes them feel that it is unnecessary to connect with external parties to be empowered.

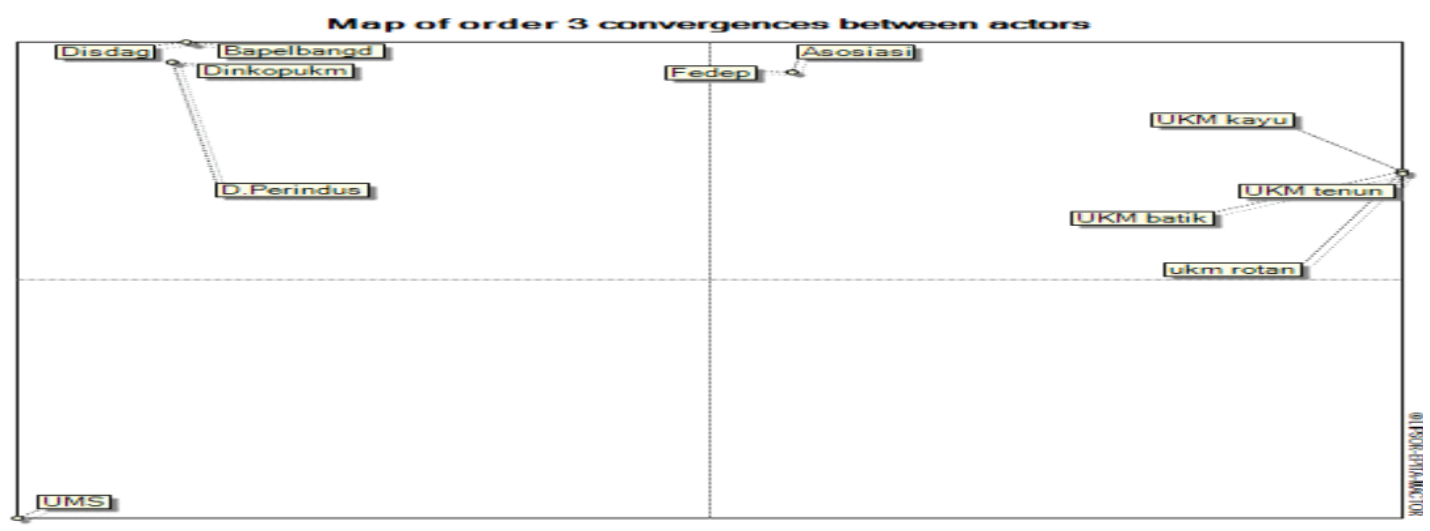

Figure 6: Map of Convergences Between Actor Source: Stakeholder Analysis based on MACTOR (2018).

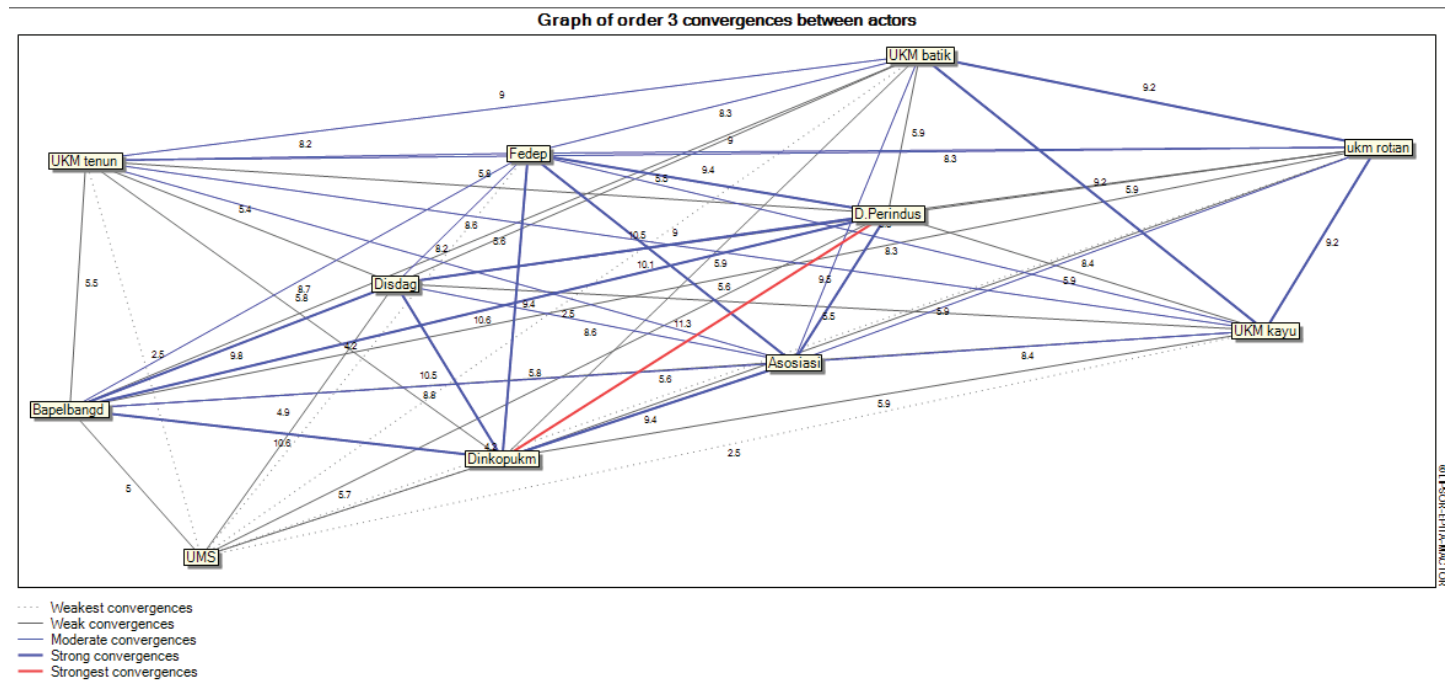

Figure 7: Graph of Convergences Between Actor Source: Stakeholder Analysis based on MACTOR (2018).

Figure 7 shows a clustered convergence divided into two major groups. The first group includes SMEs and association. The second group includes Department of 
Planning, Research and Regional Development (Bappelbangda), Department of SMEs, Department of Commerce, Department of Industry and Labor. Businessman (SMEs) are an interesting actor because they have influence and independent.

The convergences matrix shows the relationships between actors on objectives. The convergences matrix on the third order is a weighted matrix that considers the actors, objectives and competitiveness of each actor. The influence and dependence of actors as a weighted. Figure 8 shows that Department of Industry and Labor has a strong network with department of cooperation and SMEs. While other actors have moderate and weak networks. The results of mactor indicate that Department of Industry and Labor, and department of cooperation and SMEs are actors that can be accepted by all parties and as drivers of the alliance among stakeholders.

The institutional development of the creative industry is under the coordination of industry and labor agencies, but many training and SMEs training activities are conducted by the cooperative and SME office of Sukoharjo Regency so that operationally these two institutions are the most influential in the development of creative industries, these findings are reinforced by [5]. Another interesting finding is that creative industries are the most influential business actors in the development of creative industries. Creative industry development model in sukoharjo district which is proposed is cooperation 2 main groups of stakeholders, namely business actor, association and government.

\section{Conclusion}

It can be concluded that stakeholders representing the main actors of creative economic development in Sukoharjo are Department of Planning; Research and Regional Development (Bappelbangda); Department of SMEs; Department of Commerce; Department of Industry and Labor and; University; FEDEP; Association; (8) Furniture SMEs; (9) Rattan SMEs, (10) Batik SMEs, and (11) Tenun lurik SMEs. (2) Stakeholders with the highest influence are SMEs, so they can become the central figure in develop of creative industries. (3) Objectives such as profit, network, main duty, and local income (PAD) receive positive response from all actors, meaning that all actors agree with these objectives.

The creative industry development model is determined by the convergent level among stakeholders. The convergence are divided into three groups according to the interests of each stakeholder, they are (a) SMEs and association. They should be determined meticulously since the relationship between goals is unstable. (b) Department of Planning, Research and Regional Development (Bappelbangda), Department of SMEs, Department of Commerce, Department of Industry and Labor. This quadrant includes 
objective that have strong strength and weak dependence. The objectives are the key factor in creative industries development, and (c) university. The objective is less related to creative industries development and may have few relationships that will be eliminated from the objectives of stakeholders in creative industries development.

\section{References}

[1] Mangifera, Lia (2016), Strategi Pengembangan Industri lurik sebagai produk unggulan daerah. Prosiding Seminar nasional 'Tantanngan dan startegi pengembangan bisnis dalam peningkatan ekonomi kreatif, Universitas Muhamamdiyah Sidoharjo, pp 224235

[2] Mangifera, Lia (2016), Pengembangan Industri Kreatif Produk batik Tulis melaui value chain analysis. The $3^{\text {rd }}$ University Research Colloqium (URECOL), Sekolah Tinggi Ilmu Kesehatan Kudus, pp 157-166

[3] Godet, M., 1991. Actors' Move and Strategis: The MACTOR Method An air transport. Futures Journal, (August), pp.605 - 622.

[4] Rees, G.H. et al., 2017. Data gathering for actor analyses: A research note on the collection and aggregation of individual respondent data for MACTOR. Future Journal, 9(1), pp.115-137.

[5] Isa Muzakar. 2016. Model Penguatan Kelembagaan Industri Kreatif Kuliner Sebagai Upaya Pengembangan Ekonomi Daerah. Proceding Seminar Nasional Ekonomi Bisnis 2016, 17 September 2016, Universitas Muhammadiyah Sidoarjo pp 352-361 